\title{
Evaluation of Growth and Morphological Pattern of Mycorrhization in Cowpea [Vigna unguiculata (L.)] Fertilized With Phosphorus
}

\author{
José Maria Tupinambá da Silva Júnior ${ }^{1}$, Paulo Furtado Mendes Filho ${ }^{1}$, Vânia Felipe Freire Gomes ${ }^{1}$, \\ Ricardo Luiz Lange Ness ${ }^{2}$, Aldênia Mendes Mascena de Almeida ${ }^{1}$ \& Kaio Gráculo Vieira Garcia ${ }^{1}$ \\ ${ }^{1}$ Department of Soil Science, Federal University of Ceará, Fortaleza, Ceará, Brazil \\ ${ }^{2}$ Federal University of Cariri, Juazeiro do Norte, Ceará, Brazil \\ Correspondence: José Maria Tupinambá da Silva Júnior, Department of Soil Science, Federal University of \\ Ceará, Fortaleza, Ceará, Brazil. Tel: 55-85-989-681-204. E-mail: jmtsilvajunior@gmail.com
}

Received: July 28, 2018 Accepted: September 1, $2018 \quad$ Online Published: October 15, 2018

doi:10.5539/jas.v10n11p414 URL: https://doi.org/10.5539/jas.v10n11p414

\begin{abstract}
Microorganisms perform important functions in the soil and, among these organisms, the role of arbuscular mycorrhizal fungi (AMF) in plant growth should be highlighted. AMF colonize the roots of most plant species and their beneficial functions in plant development include increased absorption of nutrients from the soil, especially those of low mobility such as phosphorus (P). Evaluating agricultural practices conducted by farmers, such as phosphate fertilization, and observing how they will influence AMF activity in benefiting plant growth should be prioritized. Thus, an experiment was conducted in greenhouse to evaluate the effect of phosphate fertilization on the growth of cowpea plants colonized by AMF and to know which morphological pattern of colonization prevails in their roots. Five $\mathrm{P}$ doses and a control treatment, without fertilization, were added to the soil. Cowpea plants respond to phosphate fertilization up to the dose of $240.50 \mathrm{mg} \mathrm{P} \mathrm{kg}^{-1}$ soil, for shoot dry mass and in the dose of $150 \mathrm{mg} \mathrm{P} \mathrm{kg}^{-1}$ soil, for plant height. The morphological pattern observed in the roots was the intermediate type, characterized by the presence of intra and intercellular hyphae and vesicles, and there was no influence of phosphate fertilization on morphology. High P contents added to the soil led to a reduction in mycorrhizal colonization in cowpea roots.
\end{abstract}

Keywords: mycorrhizae, Leguminosae, phosphate fertilization

\section{Introduction}

Cowpea [Vigna unguiculata (L.)] is one of the most important crops for the population of the North and Northeast regions of Brazil, where it is widely cultivated and consumed. In addition, its grains represent an important source of protein and minerals in the population's diet, besides having notorious socioeconomic relevance. It is a plant of the Fabaceae family which is able to fix nitrogen $(\mathrm{N})$ through the association with bacteria of the genus Rhizobium, with low demand for soil fertility, adapted to regions of hot climate (humid or semi-arid), besides being considered as tolerant to drought and moderately tolerant to salinity (Dutra et al., 2015; Gomes do Ó et al., 2017).

Soils with low levels of fertility are one of the main factors limiting cowpea production, and phosphorus (P) stands out among the nutrients affecting its growth. Therefore, agricultural practices which favor the activity of soil microorganisms, especially those whose activity directly benefit plant growth through greater absorption of nutrients, such as arbuscular mycorrhizal fungi (AMF), should be encouraged.

AMF are considered as important components in the recovery and reestablishment of vegetation in degraded areas, as well as in maintaining plant biodiversity and functions of ecosystems. Additionally, they have a relevant nutritional effect on plant growth, for promoting greater absorption of water and nutrients, especially those with low mobility such as phosphorus $(\mathrm{P})$ and copper $(\mathrm{Cu})$, contributing to greater development of plant species (Santos \& Carrenho 2011; Silva et al., 2017).

Cowpea plants, particularly those cultivated in low-fertility soils, use symbiotic interactions with AMF as a means of meeting their demand for nutrients. A more detailed study on the interaction of these fungi with these plants could represent a notable strategy in agricultural systems with limited resources, because it has been known that AMF have potential as biological input to contribute to greater growth of several plant species (Rocha et al., 2017; Abreu et al., 2018). 
The morphological pattern of AMF colonization has been classified as Arum, Paris and intermediate, the latter of which has structures of the first two types. The Paris type has intracellular hyphae, some of which are coiled, and is common in forest plants, whereas the Arum type has intracellular arbuscule and intercellular hypha, present especially in cultivated herbaceous plants. Although the factors influencing the formation of the morphological pattern of mycorrhizal association have not been fully clarified, there is evidence of the importance of this plant species and AMF species in the formation of the predominant pattern in the plant (Dickson, 2004).

Nevertheless, it is important to know which morphological pattern of AMF colonization is developing in the host plant because the ability of the fungus to colonize and provide nutrients, such as $\mathrm{P}$, may differ depending on the type of morphological pattern that will develop in the root. Considering the context presented, this study aimed to evaluate the growth and morphological pattern of AMF colonization in cowpea [Vigna unguiculata (L.)] plants cultivated in soil with increasing P doses.

\section{Material and Methods}

\subsection{Location and Climate Condition of the Experimental Area}

The experiment was conducted in greenhouse at the Department of Soil Sciences of the Federal University of Ceará (UFC), Pici Campus, in Fortaleza-CE, Brazil, for a period of 38 days after germination. According to Köppen's classification (Köppen, 1931) the climate of the region is Aw', at an altitude of $20 \mathrm{~m}$ above sea level. The city has mean temperature of $26^{\circ} \mathrm{C}$, rains concentrated between February and May, and mean rainfall of $1600 \mathrm{~mm}$, where April is the rainiest month and November is the driest one (Pessoa \& Campos, 2015). The average minimum and maximum temperatures in the greenhouse along the experiments were $28{ }^{\circ} \mathrm{C}$ and $36^{\circ} \mathrm{C}$, respectively.

\subsection{Soil}

The soil used in the experiment was collected in an area of native forest, in the $0-20 \mathrm{~cm}$ layer, at the Raposa Experimental Farm of the Federal University of Ceará (UFC), located in the municipality of Maracanaú-CE (3 $\left.30^{\prime} 66^{\prime \prime} \mathrm{S} ; 38^{\circ} 38^{\prime} 38^{\prime \prime} \mathrm{W}\right)$.

After collection, the soil was pounded to break up clods, homogenized and sieved through $2 \mathrm{~mm}$ mesh to obtain the ADFE (air-dried fine earth), and one sample was sent to the Laboratory of Analyses of Soil, Water and Plants of the Department of Soil Sciences of the Center of Agrarian Sciences of the UFC. Soil chemical and physical characteristics, determined according to the methodology proposed by EMBRAPA (1997), are presented in Table 1.

Table 1. Physical and chemical characteristics of the soil collected at the Raposa Farm in Maracanaú-CE

\begin{tabular}{|c|c|c|c|c|c|c|c|c|}
\hline $\mathrm{Ca}^{2+}$ & $\mathrm{Mg}^{2+}$ & $\mathrm{Na}^{+}$ & $\mathrm{K}^{+}$ & $\mathrm{H}^{+}+\mathrm{Al}^{3+}$ & $\mathrm{Al}^{3+}$ & $\mathrm{S}$ & $\mathrm{P}$ & $\mathrm{N}$ \\
\hline \multicolumn{7}{|c|}{ 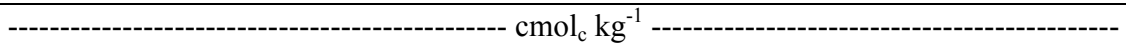 } & $\mathrm{mg} \mathrm{kg}^{-1}$ & ----- $\mathrm{g} \mathrm{kg}^{-1}$----- \\
\hline 0.50 & 0.50 & 0.16 & 0.23 & 2.97 & 0.35 & 1.4 & 3.0 & 0.06 \\
\hline $\mathrm{pH}$ & E.C. & O.M. & $\mathrm{C}$ & Coarse Sand & Fine Sand & Silt & Clay & Textural Class \\
\hline $\mathrm{H}_{2} \mathrm{O}$ & $\mathrm{dS} \mathrm{m}^{-1}$ & \multicolumn{2}{|c|}{--------- g kg $^{-1}$-------- } & ----- & \% & 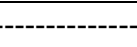 & ---------- & - \\
\hline 4.6 & 0.29 & 1.24 & 0.72 & 52.5 & 30.8 & 13.6 & 3.1 & Loamy Sand \\
\hline
\end{tabular}

Note. Organic matter (OM); Electrical conductivity (EC).

\subsection{Experiment Installation, Conduction and Design}

The soil was distributed in $5 \mathrm{~L}$ plastic pots, $4 \mathrm{~kg}$ of soil in each pot. Cowpea seeds were donated by the Company of Technical Assistance and Rural Extension of Ceará (EMATERCE). Based on chemical analysis results, soil fertility was corrected with respect to the elements nitrogen and potassium, according to the adaptation of the recommendation of the Manual of Fertilization and Liming of Ceará (Aquino et al., 1993).

Nitrogen $(\mathrm{N})$ fertilization was split into two portions, with the first application at sowing, $0.5 \mathrm{~g}$ of $\mathrm{N}$ per pot. The second application, with the same dose, was carried out 20 days after the first one. Potassium (K) fertilization was also split in the same way as $\mathrm{N}$. At planting, the first application with $0.5 \mathrm{~g}$ of $\mathrm{K}$ per pot and the second application with the same amount of $\mathrm{K}$ after 20 days, along with $\mathrm{N}$. The sources of $\mathrm{N}$ and $\mathrm{K}$ were Urea $\left(\mathrm{NH}_{2} \mathrm{CONH}_{2}\right)$ and Potassium Chloride (KCl).

To increase the $\mathrm{pH}$ of the soil solution, which was initially acid, 4.6 (Table 1), each pot received $4 \mathrm{~g}$ of dolomitic limestone, whose chemical composition is: $\mathrm{CaO}(32 \%)$ and $\mathrm{MgO}(13 \%)$, with $\mathrm{RNV}$ of $45 \%$. After application, the 
soil was incubated for a 25-day period of reaction, and soil moisture was kept close to field capacity with periodic irrigations until obtaining $\mathrm{pH}$ 6.05. Then, five seeds of cowpea were planted at $3 \mathrm{~cm}$ depth and thinning was carried out 10 days after germination, leaving two plants per plot, which were chosen based on size and uniformity.

Plants were irrigated every day with $100 \mathrm{~mL}$ of water from the Water and Sewage Company of Ceará (CAGECE), in order to maintain soil moisture near field capacity, along the entire experimental period, which corresponded to 38 days after thinning. The experimental design adopted was completely randomized $(0 ; 50 ; 100 ; 150 ; 200 ; 250$ $\mathrm{mg}$ of $\mathrm{P} \mathrm{kg}^{-1}$ of soil), with six treatments and five replicates, totaling 30 plots. The source used for phosphate fertilization was Triple Superphosphate $\left(\mathrm{Ca}\left(\mathrm{H}_{2} \mathrm{PO}_{4}\right) 2 \mathrm{H}_{2} \mathrm{O}\right)$, with $46 \%$ of phosphorus in the form of $\mathrm{P}_{2} \mathrm{O}_{5}$, applied in a single dose at sowing.

\subsection{Plant Height, Shoot Dry Mass and Phosphorus Content (P)}

Plant height $(\mathrm{cm})$ was measured with a graduated ruler and was considered as the mean of the heights of both plants in each pot. The collected plants were divided into shoots (leaves and stems or stalks) and root system.

Shoot samples were separately placed in paper bags and dried in a forced air circulation oven at temperature of $65-70{ }^{\circ} \mathrm{C}$ for 72 hours until reaching constant weight. Then, these samples were separately weighed on a scale with $0.001 \mathrm{~g}$ sensitivity. The root system was washed in running water to remove any soil debris and kept under refrigeration in a 70\% alcohol solution until evaluation of root colonization.

After drying in the oven, the material was ground in Wiley-type mill and sieved through a $2.0 \mathrm{~mm}$ mesh for chemical analysis. The extracts for analysis of $\mathrm{P}$ contents were obtained by nitric-perchloric digestion and determined by colorimetry, following the procedures described by Malavolta et al. (1997).

\subsection{Root Mycorrhizal Colonization and Morphological Pattern of Mycorrhization}

To determine root mycorrhizal colonization, roots were kept in alcoholic solution until the procedure was carried out. Roots were cleared and stained for colonization analysis following the methodology adapted by Koske and Gemma (1989), and colonization percentage was obtained according to McGonigle et al. (1990).

The identification of AMF structures observed in the roots after the staining procedure was used to classify the morphological pattern of mycorrhization as Arum, Paris or intermediate, according to Dickson (2004).

\subsection{AMF Spore Density}

AMF spores were extracted from $100 \mathrm{~g}$ of soil by wet sieving according to the procedures described by Gedermann and Nicolson (1963), followed by centrifugation in 50\% sucrose (Jenkins, 1964).

\subsection{Statistical Analysis}

The data were initially subjected to Shapiro-Wilk test at 0.05 probability level to check if they had normal distribution. If normality was observed, the parameters were subjected to the test of homogeneity of variances (Levene's test). For variables with normal distribution and homogeneous variances, analysis of variance (ANOVA) was carried out and, if significant $(\mathrm{p}<0.05)$, their means were compared by Tukey test $(\mathrm{p}<0.05)$. Variables with normal distribution, but heterogeneous variances, were subjected to Brown-Forsythe test and, when significant value $(\mathrm{p}<0.05)$ was found, their means were compared by Games-Howell test. Variables with non-parametric distribution were subjected to Kruskal-Wallis test and, when significant value $(\mathrm{p}<0.05)$ was observed, their means were compared by the stepwise method (Field, 2009).

Regression analysis was carried to verify which was the best model to represent the variables analyzed as a function of P doses. Statistical analysis was performed in the software package SPSS (Statistical Package for the Social Sciences), Version 20 (IBM, 2011).

\section{Results and Discussion}

\subsection{Plant Height, Shoot Dry Mass and Phosphorus Content (P)}

According to the Shapiro-Wilk test, the variables plant height (PH), shoot dry mass (SDM) and phosphorus content (P) did not follow normal distribution $(\mathrm{p}<0.05)$. Thus, the Kruskal-Wallis test was applied and, when significance was observed $(p<0.05)$, treatment means were compared by the stepwise method. Phosphate fertilization had significant influence on the variables analyzed (Table 2). 
Table 2. Plant height $(\mathrm{PH})$, shoot dry mass (SDM) and phosphorus content $(\mathrm{P})$ in a soil fertilized with increasing doses of $\mathrm{P}$ and cultivated with cowpea

\begin{tabular}{llll}
\hline Treatments & PH $(\mathrm{cm})$ & SDM $(\mathrm{g})$ & $\mathrm{P}\left(\mathrm{g} \mathrm{kg}^{-1}\right)$ \\
\hline $\mathrm{T} 1: 0 \mathrm{mg} \mathrm{P} \mathrm{k}^{-1}$ soil & $20.41 \mathrm{c}$ & $1.29 \mathrm{c}$ & $1.15 \mathrm{~d}$ \\
$\mathrm{~T} 2: 50 \mathrm{mg} \mathrm{P} \mathrm{k}^{-1}$ soil & $49.75 \mathrm{~b}$ & $4.01 \mathrm{~b}$ & $1.41 \mathrm{~d}$ \\
$\mathrm{~T} 3: 100 \mathrm{mg} \mathrm{P} \mathrm{k}^{-1}$ soil & $55.04 \mathrm{~b}$ & $4.52 \mathrm{~b}$ & $2.63 \mathrm{c}$ \\
$\mathrm{T} 4: 150 \mathrm{mg} \mathrm{P} \mathrm{k}^{-1}$ soil & $79.02 \mathrm{a}$ & $5.76 \mathrm{a}$ & $3.24 \mathrm{~b}$ \\
$\mathrm{~T} 5: 200 \mathrm{mg} \mathrm{P} \mathrm{k}^{-1}$ soil & $54.02 \mathrm{~b}$ & $5.37 \mathrm{ab}$ & $4.91 \mathrm{a}$ \\
$\mathrm{T} 6: 250 \mathrm{mg} \mathrm{P} \mathrm{kg}^{-1}$ soil & $48.81 \mathrm{~b}$ & $4.93 \mathrm{ab}$ & $6.00 \mathrm{a}$ \\
\hline
\end{tabular}

Note. Means followed by the same letter in the column do not differ by the stepwise method $(\mathrm{p}<0.05)$.

The $\mathrm{P}$ doses added to the soil had significant effect on cowpea height $(\mathrm{PH})$ and its highest value occurred at dose of $150 \mathrm{mg} \mathrm{P} \mathrm{kg}^{-1}$ soil, significantly differing from the other treatments (Table 2). The treatment $\mathrm{T} 1$, which did not receive phosphate fertilization, showed the lowest value of $\mathrm{PH}$, confirming that absence or low content of $\mathrm{P}$ in the soil is a limiting factor for cowpea growth. Sousa et al. (2014) also observed significant effect on the height of cowpea plants grown under organic fertilization with biofertilizer, whose $\mathrm{P}$ concentration is $1.1 \mathrm{~g} \mathrm{~L}^{-1}$, in comparison to non-fertilized plants.

The quadratic regression model describing $\mathrm{PH}$ is presented in Figure 1A, and maximum height was obtained at dose of $150 \mathrm{mg} \mathrm{P} \mathrm{kg}^{-1}$ soil. A negative effect of the excessive availability of $\mathrm{P}$ on cowpea plants can also be seen (Figure 1A). Nakayama et al. (2013) obtained similar results evaluating the effect of fertilization with difference doses of organo-mineral fertilizer on the height of common beans (Phaseolus vulgaris). These authors found that doses higher than $100 \mathrm{mg} \mathrm{kg}^{-1}$ led to a quadratic reduction in PH. Coutinho et al. (2014), also evaluating phosphate fertilization on cowpea plants, observed similar result to those in the present study for $\mathrm{PH}$, at $\mathrm{P}$ doses above $200 \mathrm{~kg}$ $\mathrm{ha}^{-1}$.
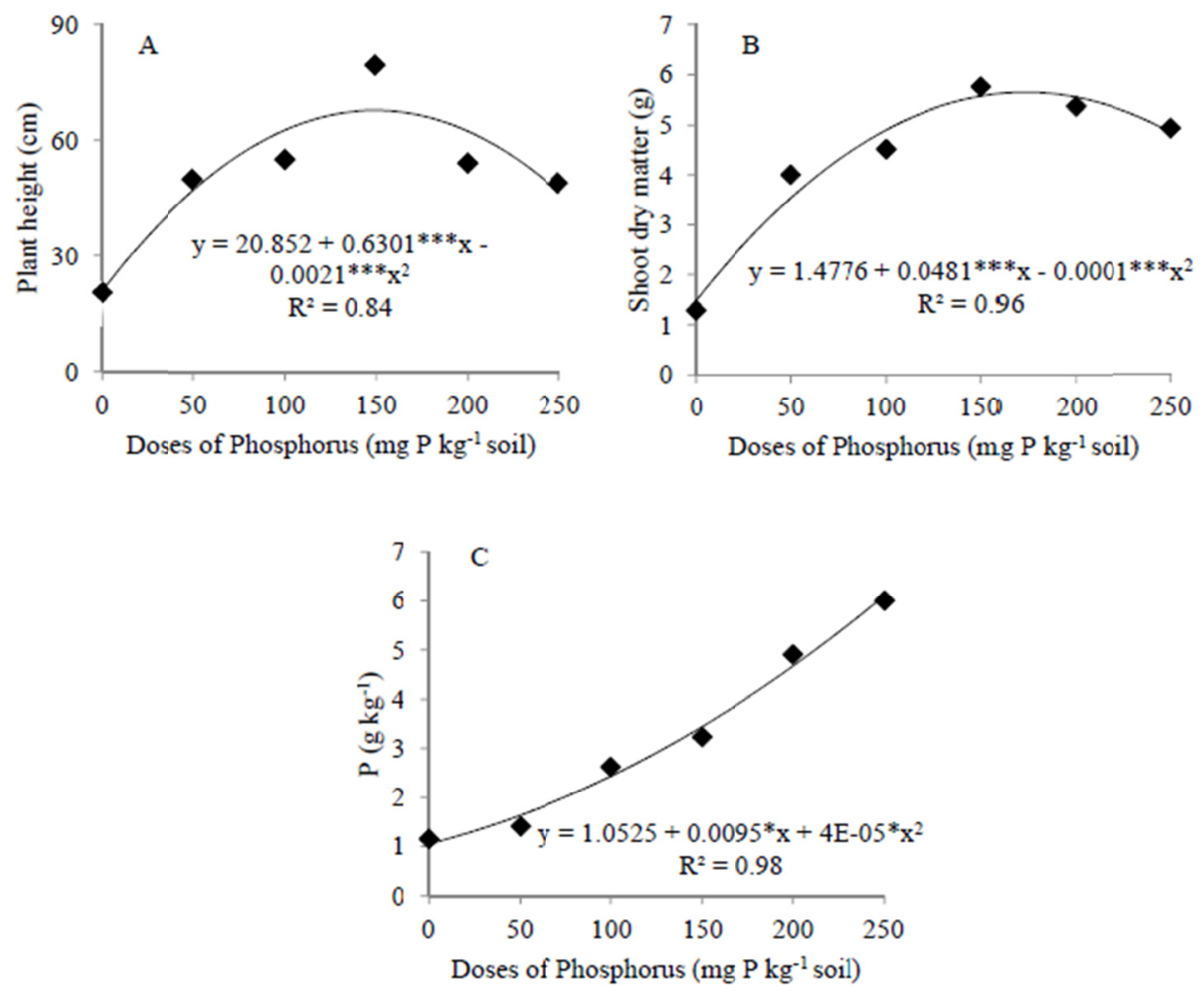

Figure 1. Plant height (A), shoot dry matter (B) and phosphorus content (C) in cowpea plants fertilized with phosphorus (mg P kg ${ }^{-1}$ soil). *** Significant at $(\mathrm{p}<0.001) . *$ Significant at $(\mathrm{p}<0.05)$ 
Coelho et al. (2012) observed greater growth due to the presence of AMF when plants were grown in soil with low availability of nutrients, because soils with high levels of fertility, especially of P, as in treatments T5 (200 mg P $\mathrm{kg}^{-1}$ soil) and $\mathrm{T} 6$ (250 mg P kg${ }^{-1}$ soil), are not favorable to mycorrhizal colonization in plant roots. Consequently, the beneficial effect of AMF, which promotes plant growth, will be smaller.

For shoot dry mass (SDM), a quadratic model had the best fit (Figure 1B). SDM increased with the addition of P to the soil and its maximum value was obtained at dose of $240.50 \mathrm{mg} \mathrm{P} \mathrm{kg}^{-1}$ soil. Higher doses limited the growth of cowpea plants. As can be seen in Figure 1B, the treatment with highest P dose (T6: $250 \mathrm{mg} \mathrm{P} \mathrm{kg}^{-1}$ soil) reduced plant growth by up to $14.41 \%$ compared to the treatment with highest value of SDM. As already observed by Schiavo et al. (2010), high contents of nutrients, and more specifically of $\mathrm{P}$, can reduce the growth of mycorrhized plants because, in general, these plants reach maximum development at low doses of $\mathrm{P}$.

The attributes which can control P demand and supply to the plant, and thus its dependence on the nutrient, are related to the morphological and physiological characteristics of the host. Because of that, the most adequate $\mathrm{P}$ content in the soil for the response to mycorrhizae is highly variable between plant species and cultivars, and differences occur even between plants that are genetically very close (Clement \& Habte, 1995). Fernandes et al. (2013) reported increase in the SDM of cowpea plants grown in soil fertilized with $\mathrm{P}$, and the estimated doses of 45 and $48 \mathrm{~kg} \mathrm{ha}^{-1}$ of $\mathrm{P}_{2} \mathrm{O}_{5}$ led to highest SDM production. Higher doses of $\mathrm{P}$ caused reduction in SDM, as also observed in the present study.

Phosphate fertilization through increasing doses of $\mathrm{P}$ in the soil led to significant increase in $\mathrm{P}$ content in cowpea shoots (Figure 1C). Similar results have been found in several previous studies, and this response is related to the increase in $\mathrm{P}$ availability in the soil solution due to the addition of soluble fertilizer (triple superphosphate). $\mathrm{P}$ contents in the tissues increased with increasing doses of $\mathrm{P}$ (Figure 1C).

Nascente et al. (2014) also observed increment in P content in the shoots of common beans with the increase of $\mathrm{P}$ doses in the soil in a field experiment. According to these authors, $\mathrm{P}$ is an essential element to the metabolism of common bean, which has a well-defined response to the addition of $\mathrm{P}$ in the soil, thus contributing significantly to the increase in grain yield and root development, favoring the increase in the number of pods and grain mass (Zucareli et al., 2010). Consequently, the importance of phosphate fertilization in cowpea cultivation, especially in soils with reduced fertilized, is unequivocal.

\subsection{Root Mycorrhizal Colonization and Morphological Pattern of Mycorrhization}

Mycorrhization in cowpea plants occurred naturally, due to the abundance of native spores in the soil. The data of arbuscular mycorrhizal colonization had a non-parametric distribution according to the Shapiro-Wilk test $(\mathrm{p}<$ 0.05). Since this variable had a non-parametric distribution, Kruskal-Wallis test was applied and, when significance was observed at 0.05 level, treatment means were compared by the stepwise method (Table 3 ). The treatment T3: $100 \mathrm{mg} \mathrm{P} \mathrm{kg}^{-1}$ soil had the highest percentage of mycorrhizal colonization, significantly differing from the others. There was no statistically significant difference between T1: $0 \mathrm{mg} \mathrm{P} \mathrm{kg}^{-1}$ soil and T4: $150 \mathrm{mg} \mathrm{P}$ $\mathrm{kg}^{-1}$ soil treatments and from the treatment $\mathrm{T} 4$, there was a reduction in mycorrhizal colonization, a behavior related to the high contents of $\mathrm{P}$ added to the soil, which was also observed by Vitorazi Filho et al. (2012).

Table 3. Mycorrhizal colonization in the roots of cowpea grown in soil fertilized with increasing doses of $\mathrm{P}$

\begin{tabular}{ll}
\hline Treatments & Mycorrhizal colonization $(\%)$ \\
\hline T1: $0 \mathrm{mg} \mathrm{P} \mathrm{kg}^{-1}$ soil & $46.30 \mathrm{c}$ \\
T2: $50 \mathrm{mg} \mathrm{P} \mathrm{kg}^{-1}$ soil & $65.80 \mathrm{~b}$ \\
T3: $100 \mathrm{mg} \mathrm{P} \mathrm{kg}^{-1}$ soil & $77.60 \mathrm{a}$ \\
T4: $150 \mathrm{mg} \mathrm{P} \mathrm{kg}^{-1}$ soil & $43.50 \mathrm{c}$ \\
T5: $200 \mathrm{mg} \mathrm{P} \mathrm{kg}^{-1}$ soil & $41.10 \mathrm{~d}$ \\
T6: $250 \mathrm{mg} \mathrm{P} \mathrm{kg}^{-1}$ soil & $36.20 \mathrm{e}$ \\
\hline
\end{tabular}

Note. Means followed by the same letter in the column do not differ by the stepwise method $(\mathrm{p}<0.05)$.

Alguacil et al. (2010) found similar result evaluating mycorrhizal colonization in Centrosema macrocarpum Benth. fertilized with different doses of $\mathrm{P}$ (rock phosphate or diammonium phosphate). Regardless of the source used in fertilization, at the highest dose applied to the soil the mycorrhizal colonization was significantly reduced in comparison to the lowest dose of $\mathrm{P}$ used in the experiment. According to these authors, although the mechanism determining the influence of phosphate fertilization on AMF community is mostly unknown, the increase in soil 
fertility can be related to a lower dependence of the plant on the AMF.

A quadratic regression model fitted to the data (Figure 2). The percentage of mycorrhizal colonization increased with the addition of $\mathrm{P}$, up to the dose of $89.90 \mathrm{mg} \mathrm{Pg} \mathrm{k}^{-1}$ soil, and decreased from this point on, as an effect of the high availability of $\mathrm{P}$ in the soil.

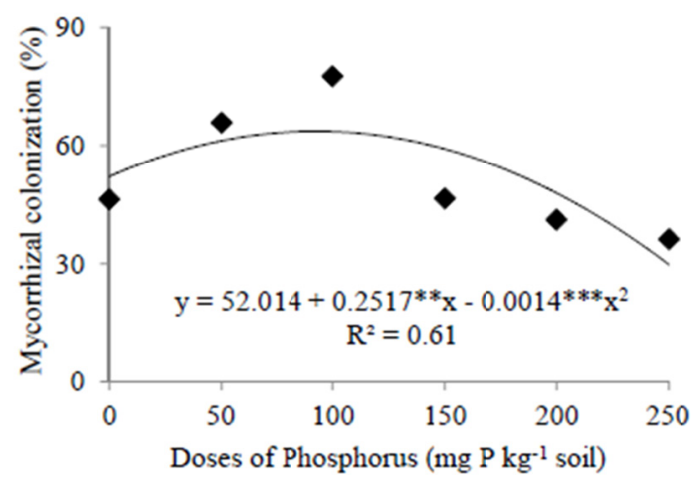

Figure 2. Mycorrhizal colonization in soil fertilized with phosphorus and cultivated with cowpea. ** and *** Significant at $(\mathrm{p}<0.01)$ and at $(\mathrm{p}<0.001)$, respectively

Machineski et al. (2011) also found reduction in the percentage of mycorrhizal colonization with the increment in $\mathrm{P}$ doses in soil cultivated with castor bean (Ricinus communis). Lowest percentage of mycorrhizal colonization occurred at the highest dose of P, as also observed in the present study. Such decrease can be considered as normal, because of the inhibition of the establishment of symbiosis under high contents of $\mathrm{P}$, with consequent reduction in colonization intensity.

According to Smith and Read (2008), higher mycorrhizal colonization can be associated with soils with low availability of $\mathrm{P}$ and this may induce an increase in plant growth. The beneficial effect on plant growth due to the presence of AMF has been found, in a similar way, in other studies with the cowpea crop (Abdel-Fattah et al., 2011), among other plant species (Cordeiro et al., 2015). It is important to emphasize that, according to Hippler et al. (2011), the percentage of mycorrhizal colonization is not always a safe parameter to define the positive effect of AMF on the growth of the host plant. In some plants, very low colonization rates such as $5 \%$ were already sufficient to allow satisfactory plant development (Karanika et al., 2008).

The morphological pattern of mycorrhizal colonization observed in cowpea plants was of the intermediate type in all treatments (Figure 3). The structures observed were intracellular hyphae, intercellular hyphae, coiled hyphae and vesicles, thus characterizing the intermediate type, based on the description of morphological patterns of colonization done by Dickson (2004).
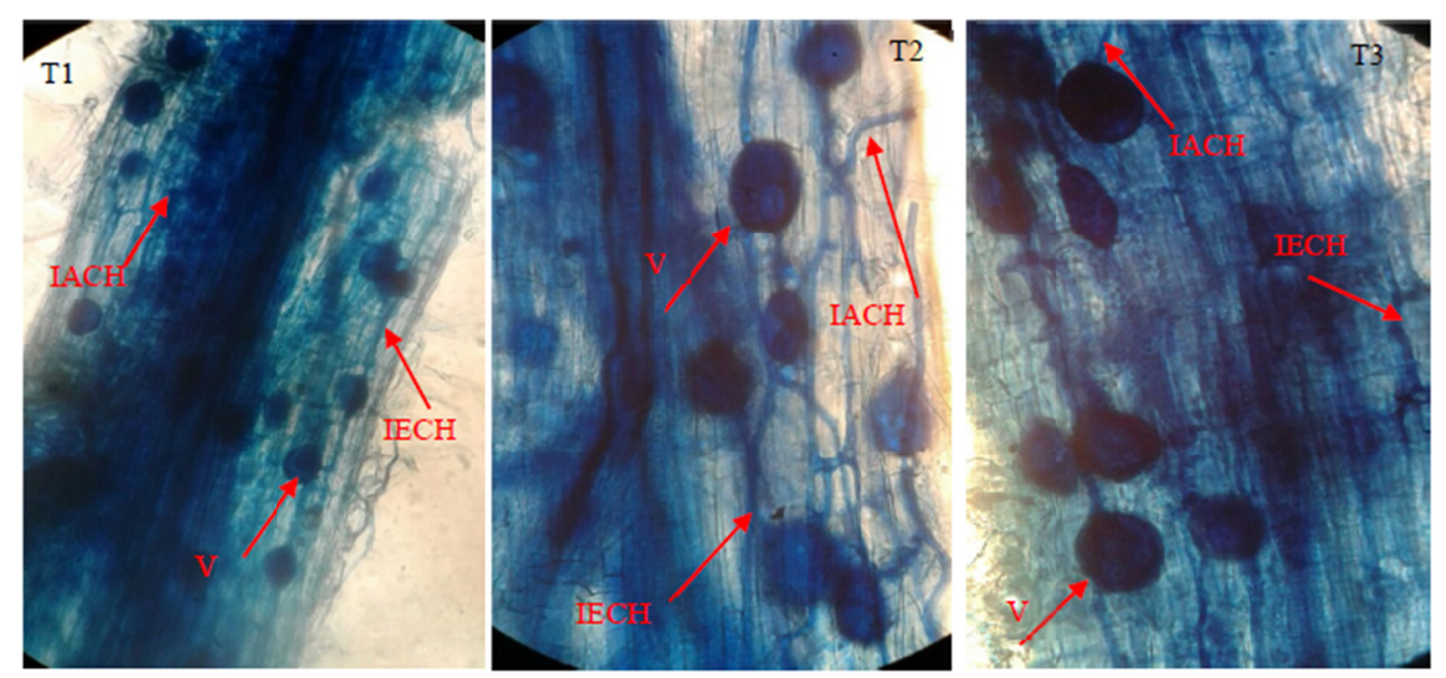


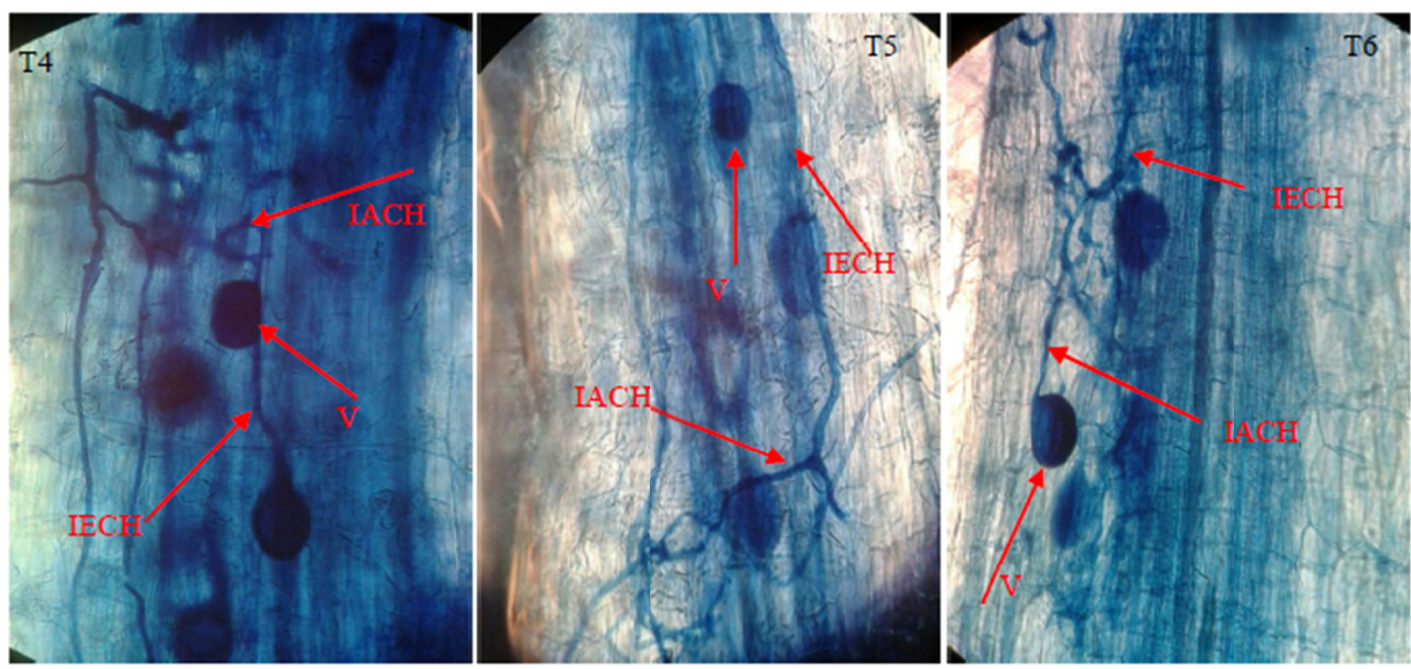

Figure 3. Morphological pattern of mycorrhizal colonization in the roots of cowpea grown in soil under different doses of P. V: vesicle; IACH: intracellular hypha; IECH: intercellular hypha

Source: Created by the authors (2018).

For Sousa et al. (2013), root colonization by AMF can be characterized by the intracellular growth of hyphae in the cortical tissue, even if the hyphae do not differentiate into arbuscules. Additionally, vesicles and coiled hyphae may occur, as observed in the present study and also by Camargo-Ricalde et al. (2012). According to Smith and Smith (2011), intracellular hyphae, arbuscules and structures of the intermediate morphology are involved in the transfer of nutrients, such as $\mathrm{P}$, to the host plant and not only arbuscules.

Rooney et al. (2011) found similar results to those of the present study, observing few arbuscules in roots of Populus euramericana, which may be related to environmental factors because they influence arbuscule development. According to these authors, in an experiment conducted with Populus euramericana, arbuscule frequency increased over time and compared with the presence of vesicles, being higher with the inoculation of Glomus intraradices compared with the other AMF species tested in the experiment.

Uma et al. (2012) evaluated the morphological pattern of AMF in several plant species and found the presence of the three morphological types, Arum, Paris and intermediate, with predominance of the intermediate type. For these authors, the morphological pattern of AMF depends more on plant characteristics than on fungi because some factors affecting plant growth, including factors of soil, can also contribute to the morphological variability observed in the roots of plant species.

However, in an experiment carried out with five AMF species and one plant species, different morphological patterns were found depending on which AMF species was inoculated in the plant (Cavagnaro et al., 2001). Thus, the morphological pattern of AMF does not depend only on the plant, it is also influenced by the AMF species, as already stated by Dickson (2004). Uma et al. (2010) reinforces this idea, because in the evaluation of morphological pattern in plants of the Zingiberaceae and Costaceae families, these authors found Arum, Paris and intermediate types, regardless of belonging to the same botanical family. This corroborates the idea that the plant species and the AMF species colonizing the roots are important in determining the morphological pattern in the plant.

\subsection{Spore Density (SpD)}

Spore density $(\mathrm{SpD})$ had non-parametric distribution according to the Shapiro-Wilk test at 0.05 probability level. Thus, Kruskal-Wallis test at 0.05 probability was applied and, since there was significance, treatment means were compared by the stepwise method (Table 4). The treatment T3: $100 \mathrm{mg} \mathrm{P} \mathrm{kg}^{-1}$ soil had highest density (1020 spores per 100 grams of soil), differing from the others. The treatment T6: $250 \mathrm{mg} \mathrm{P} \mathrm{kg}^{-1}$ soil showed the lowest SpD and, from the treatment T4: $150 \mathrm{mg} \mathrm{P} \mathrm{kg}^{-1}$ soil, the number of spores decreased due to the high contents of $\mathrm{P}$ in the soil (Table 4). 
Table 4. Spore density in soil fertilized with increasing doses of $\mathrm{P}$ and cultivated with cowpea

\begin{tabular}{ll}
\hline Treatments & Spore density \\
\hline $\mathrm{T} 1: 0 \mathrm{mg} \mathrm{P} \mathrm{kg}^{-1}$ soil & $732 \mathrm{~b}$ \\
$\mathrm{~T} 2: 50 \mathrm{mg} \mathrm{P} \mathrm{k}^{-1}$ soil & $616 \mathrm{c}$ \\
$\mathrm{T} 3: 100 \mathrm{mg} \mathrm{Pg}^{-1}$ soil & $1020 \mathrm{a}$ \\
$\mathrm{T} 4: 150 \mathrm{mg} \mathrm{Pg}^{-1}$ soil & $696 \mathrm{bc}$ \\
T5: $200 \mathrm{mg} \mathrm{P} \mathrm{kg}^{-1}$ soil & $648 \mathrm{bc}$ \\
T6: $250 \mathrm{mg} \mathrm{Pg}^{-1}$ soil & $440 \mathrm{~d}$ \\
\hline
\end{tabular}

Note. Means followed by the same letter in the row do not differ by the stepwise method $(\mathrm{p}<0.05)$.

Carneiro et al. (2010) evaluated the influence of mycorrhizal inoculation and phosphate fertilization on Stylosanthes and observed a similar behavior, with reduction in spore density as P doses in the soil increased. These authors report that the number of spores can vary according to the different characteristics, such as predominant species of mycorrhizal fungus in the soil, host plant, climatic conditions, etc. However, the reduction in the number of AMF spores with the increase in P doses in the soil does not always occur. Moreira et al. (2012) observed no variation in spore density as a function of increasing doses of P in a soil cultivated with Araucaria angustifolia.

The quadratic regression model had the best fit, with maximum number of AMF spores in the dose $149.55 \mathrm{mg} P$ $\mathrm{kg}^{-1}$ soil (Figure 4).

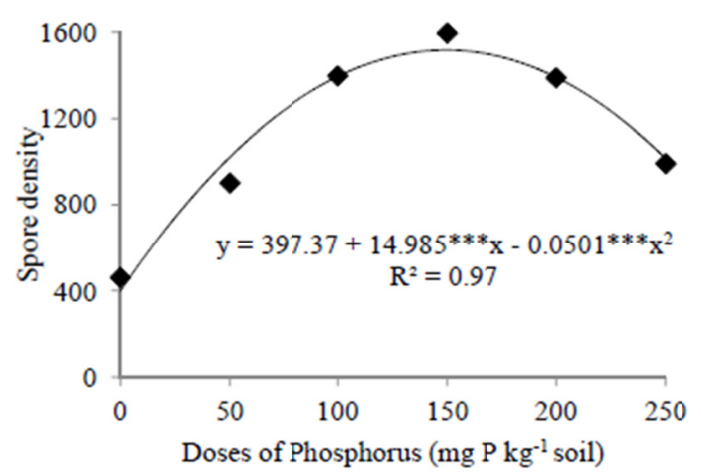

Figure 4. AMF spore density in soil fertilized with phosphorus and cultivated with cowpea. *** Significant at $(\mathrm{p}<0.001)$.

The interaction between AMF and other microorganisms can favor the increase in spore density in the cowpea crop, as observed by Mirdhe and Lakshman (2014), evaluating the inoculation with AMF, Rhizobium and phosphate-solubilizing bacteria in Vigna unguiculata plants. Triple inoculation increased the number of spores compared with single inoculation or double inoculation with these microorganisms.

\section{Conclusions.}

Cowpea plants responded to phosphate fertilization up to the dose of $240.50 \mathrm{mg} \mathrm{P} \mathrm{kg}^{-1}$ soil, for shoot dry mass and in the dose of $150 \mathrm{mg} \mathrm{P} \mathrm{kg}^{-1}$ soil, for plant height.

High P contents added to the soil led to reduction in mycorrhizal colonization in cowpea roots.

The morphological pattern of arbuscular mycorrhizal colonization was the intermediate type, and there was no influence of phosphate fertilization on its morphology.

\section{References}

Abdel-Fattaha, G. M., El-Haddadb, S. A., Hafezc, E. E., \& Rashadd, Y. M. (2011). Induction of defense responses in common bean plants by arbuscular mycorrhizal fungi. Microbiological Research, 166(4), 268-281. https://doi.org/10.1016/j.micres.2010.04.004 
Abreu, G. M., Schiavo, J. A., Abreu, P. M., Bobadilha, G. dos S., \& Rosset, J. S. (2018). Crescimento inicial e absorção de fósforo e nitrogênio de Enterolobium contortisiliquum inoculada com fungos micorrízicos arbusculares. Revista de Ciências Agrárias, 41(1), 156-164.

Alguacil, M. del M., Lozano, Z., Campoy, M. J., \& Roldán, A. (2010). Phosphorus fertilisation management modifies the biodiversity of AM fungi in a tropical savanna forage system. Soil Biology \& Biochemistry, 42(7), 1114-1122. https://doi.org/10.1016/j.soilbio.2010.03.012

Aquino, A. B., Aquino, B. F., Hernandez, F. F. F., Holanda, F. J. M., Freire, J. M., Crisostomo, L. A., ... Fernandes, V. L. B. (1993). Recomendações de adubação e calagem para o Estado do CE (1st ed., p. 247). Fortaleza: UFC.

Camargo-Ricalde, S. L., Montaño, N. M., Rosa-Mera, C. J., \& Arias, S. A. M. (2012). Micorrizas: una gran unión debajo del suelo. Revista Digital Universitária, 13(7), 3-19.

Carneiro, R. F. V., Martins, M. A., Vásquez, H. M., \& Detmann, E. (2010). Doses de fósforo e inoculação micorrízica no cultivo de estilosantes em solo sob condições naturais. Archivos de Zootecnia, 59(227), 415-426. https://doi.org/10.4321/S0004-05922010000300009

Cavagnaro, T. R., Gao, L. L., Smith, F. A., \& Smith, S. E. (2001). Morphology of arbuscular mycorrhizas is influenced by fungal identity. New Phytologist, 151(2), 469-475. https://doi.org/10.1046/j.0028-646x. 2001.00191.x

Clement, C. R., \& Habte, M. (1995). Genotypic variation in vesicular-arbuscular mycorrhizal dependence of the pejibaye palm. Journal of Plant Nutrition, 18(9), 1907-1916. https://doi.org/10.1080/01904169509365032

Coelho, I. R., Cavalcante, U. M. T., Campos, M. A. da S., \& Silva, F. S. B. da. (2012). Uso de fungos micorrízicos arbusculares (FMA) na promoção do crescimento de mudas de pinheira (Annona squamosa L., Annonaceae). Acta Botanica Brasilica, 26(4), 933-937. https://doi.org/10.1590/S0102-33062012000400022

Cordeiro, M. A. S., Ferreira, D. A., Paulino, H. B., Souza, C. R. F., Siqueira, J. O., \& Carneiro, M. A. C. (2015). Mycorrhization stimulant based in formononetin associated to fungicide and doses of phosphorus in soybean in the Cerrado. Bioscience Journal, 31(4), 1062-1070. https://doi.org/10.14393/BJ-v31n4a 2015-26185

Coutinho, P. W. R., Silva, D. M. S., Saldanha, E. C. M., Okumura, R. S., \& Silva Júnior, M. L. da. (2014). Doses de fósforo na cultura do feijão-caupi na região nordeste do Estado do Pará. Revista Agro@mbiente, 8(1), 66-73. https://doi.org/10.18227/1982-8470ragro.v8i1.1310

Dickson, S. (2004). The Arum-Paris continuum of mycorrhizal symbioses. New Phytologist, 163, $187-200$. https://doi.org/10.1111/j.1469-8137.2004.01095.x

Dutra, A. F., Melo, A. S., Filgueiras, L. M. B., Silva, A. R. F., Oliveira, I. M., \& Brito, M. E. B. (2015). Parâmetros fisiológicos e componentes de produção de feijão-caupi cultivado sob deficiência hídrica. Revista Brasileira de Ciências Agrárias, 10(2), 189-197. https://doi.org/10.5039/agraria.v10i2a3912

EMBRAPA (Empresa Brasileira de Pesquisa Agropecuária). (1997). Manual de métodos de análise de solo. (2.ed. p. 212). Rio de Janeiro: Centro Nacional de Pesquisa de Solos.

Fernandes, A. R., Fonseca, M. R., \& Braz, A. M. de S. (2013). Produtividade de feijão caupi em função da calagem e fósforo. Revista Caatinga, 26(4), 54-62.

Field, A. (2009). Discovering statistics using SPSS (3rd ed., p. 854). London: SAGE Publications Ltd.

Gerdemann, J. W., \& Nicolson, T. H. (1963.) Spore of mycorrhizal Endogene specie extracted from soil by wet sieving and decanting. Transactive Britanish Mycology Society, 46(2), 235-244. https://doi.org/10.101 6/S0007-1536(63)80079-0

Gomes do Ó, L. M., Silva, T. C., Sousa, G. G., Saraiva, K. R., \& Souza, M. V. P. (2017). Crescimento e solutos orgânicos do feijão-caupi submetido a níveis de salinidade da água de irrigação. Revista Brasileira de Agricultura Irrigada, 11(7), 1934-1944. https://doi.org/10.7127/rbai.v11n700657

Hippler, F. W. R., Moreira, M., Dias, N. M. S., \& Hermann, E. R. (2011). Fungos micorrízicos arbusculares nativos e doses de fósforo no desenvolvimento do amendoim RUNNER IAC 8861. Revista Ciência Agronômica, 42(3), 605-610. https://doi.org/10.1590/S1806-66902011000300005

IBM Corp. (2011). IBM SPSS Statistics for Windows (Version 20.0). Armonk, NY: IBM Corp. 
Jenkins, W. R. (1964). A rapid centrifugal-flotation technique for separating nematodes from soil. Plant Disease Reporter, 48, 692.

Karanika, E. D., Voulgaria, O. K., Mamolos, A. P., Alifragis, D. A., \& Veresoglou, D. S. (2008). Arbuscular mycorrhizal fungi in Northern Greece and influence of soil resources on their colonization. Pedobiologia, 51(06), 409-418. https://doi.org/10.1016/j.pedobi.2007.11.002

Koske, R. E., \& Gemma, J. N. (1989). A modified procedure for staining roots to detect VA mycorrhizas. Mycological Research, 92(4), 486-505. https://doi.org/10.1016/S0953-7562(89)80195-9

Köppen, W. (1931). Grundriss der Klimakunde: Outline of climate science (p. 388). Berlin: Walter de Gruyter.

Machineski, O., Balota, E. L., \& Souza, J. R. P. (2011). Resposta da mamoneira a fungos micorrízicos arbusculares e a níveis de fósforo. Semina: Ciências Agrárias, 32(1), 1855-1862. https://doi.org/10.5433/ 1679-0359.2011v32Suplp1855

Malavolta, E., Vitti, G. C., \& Oliveira, S. A. (1997). Avaliação do estado nutricional das plantas (2nd ed., p. 319). Piracicaba: POTAFOS.

Mcgonigle, T. P., Miller, M. H., Evans, D. G., Fairchild, G. L., \& SWAN, J. A. (1990). A new method which gives an objective measure of colonization of roots by vesiculararbuscular mycorrhizal fungi. New Phytologist, 115, 495-501. https://doi.org/10.1111/j.1469-8137.1990.tb00476.x

Mirdhe, R. M., \& Lakshman, H. C. (2014). Synergistic interaction between arbuscular mycorrhizal fungi, rhizobium and phosphate solubilising bacteria on Vigna unguiculata (L.) verdc. International Journal of Bioassays, 3(5), 2096-2099. https://doi.org/10.21746/ijbio.2014.05.008

Moreira, M., Baretta, D., \& Cardoso, E. J. B. N. (2012). Doses de fósforo determinam a prevalência de fungos micorrízicos arbusculares em Araucaria angustifolia. Ciência Florestal, 22(4), 813-820. https://doi.org/ $10.5902 / 198050987562$

Nakayama, F. T., Pinheiro, G. A. S., \& Zerbini, E. F. (2013). Eficiência do fertilizante organomineral na produtividade do feijoeiro (Phaseolus vulgaris L.) em sistema de semeadura direta. Fórum Ambiental da Alta Paulista, 9(7), 122-138.

Nascente, A. S., Cobucci, T., Sousa, D. M. G., \& Lima, D. de P. (2014). Adubação fosfatada no sulco e foliar afetando a produtividade de grãos do feijoeiro comum. Semina: Ciências Agrárias, 35(3), 1231-1240. https://doi.org/10.5433/1679-0359.2014v35n3p1231

Pessoa, F. E. P., \& Campos, J. N. B. (2015). Ciclo diário de precipitações pluviais em intervalos de cinco minutos no município de Fortaleza. Revista Brasileira de Meteorologia, 30(2), 195-204. https://doi.org/ $10.1590 / 0102-778620140116$

Rocha, B. C. F., Santos, E. O. da S., Santos, J. G. D., Takako, A. K., \& Castro, F. J. (2017). Land use and vegetation cover on native symbionts and interactions with cowpea. Revista Brasileira de Engenharia Agricola e Ambiental, 21(2), 116-121. https://doi.org/10.1590/1807-1929/agriambi.v21n2p116-121

Rooney, D. C., Prosser, J. I., Bending, G. D., Baggs, E. M., Killham, K., \& Hodge, A. (2011). Effect of arbuscular mycorrhizal colonisation on the growth and phosphorus nutrition of Populus euramericana c.v. Ghoy. Biomass and Bioenergy, 35(11), 4605-4612. https://doi.org/10.1016/j.biombioe.2011.08.015

Santos, F. E. F., \& Carrenho, R. (2011). Diversidade de fungos micorrízicos arbusculares em remanescente florestal impactado (Parque Cinqüentenário, Maringá, Paraná, Brasil). Acta Botanica Brasilica, 25(2), 508-516. https://doi.org/10.1590/S0102-33062011000200026

Schiavo, J. A., Silva, C. A., Rosset, J. S., Secretti, M. L., Sousa, R. A. C., \& Cappi, N. (2010). Composto orgânico e inoculação micorrízica na produção de mudas de pinhão manso. Pesquisa Agropecuária Tropical, 40(3), 322-329. Retrieved from https://www.revistas.ufg.br/pat/article/view/6303/7769

Silva, M. B., Oliver, F. C., Cruz, R. M. S., Marchi, B. de A., Almas, L. R. M., \& Alberton, O. (2017). Resposta do fungo micorrízico arbuscular Rhizophagus clarus e adição de substâncias húmicas no crescimento do tomateiro (Solanum lycopersicum L.). Revista Scientia Agraria, 18(3), 123-130. https://doi.org/10.5380/ rsa.v18i3.52888

Smith, S. E., \& Smith, F. A. (2011). Roles of arbuscular mycorrhizas in plant nutrition and growth: New paradigms from cellular to ecosystem scales. The Annual Review of Plant Biology, 62, 227-50. https://doi.org/10.1146/annurev-arplant-042110-103846 
Smith, S. E., \& Read, D. J. (2008). Mycorrhizal symbiosis (3rd ed. p. 605). Califórnia: Academic Press. https://doi.org/10.1016/B978-012370526-6.50013-1

Sousa, G. G. de, Viana, T. V. de A., Lacerda, C. F. de, Azevedo, B. M. de, Silva, G. L. da, \& Costa, F. R. B. (2014). Estresse salino em plantas de feijão-caupi em solo com fertilizantes orgânicos. Revista Agro@mbiente, 8(3),359-367.https://doi.org/10.5327/Z1982-8470201400031824

Souza, A. V., Oliveira, F. J. V., Bertoni, B. W., França, S. C., \& Pereira, A. M. S. (2013). Ocorrência de fungos micorrízicos em catuaba (Anemopaegma arvense (Vell.) Stell. ex de Souza-Bignoniaceae), uma planta medicinal do Cerrado em risco de extinção. Revista Brasileira Plantas de Medicinais, 15(4), 646-654. https://doi.org/10.1590/S1516-05722013000500004

Uma, E., Muthukumar, T., Sathiyadash, K., \& Muniappan, V. (2010). Mycorrhizal and dark septate fungal associations in gingers and spiral gingers. Botany, 88(5), 500-511. https://doi.org/10.1139/B10-021

Uma, E., Sathiyadash, K., Loganathan, J., \& Muthukumar, T. (2012). Tree species as hosts for arbuscular mycorrhizal and dark septate endophyte fungi. Journal of Forestry Research, 23(4), 641-649. https://doi.org/10.1007/s11676-012-0267-z

Vitorazi Filho, J. A., Lima, K. B., Freitas, M. S. M., Martins, M. A., \& Olivares, F. L. (2012). Crescimento de mudas de maracujazeiro-doce inoculadas com fungos micorrízicos arbusculares e bactérias diazotróficas sob diferentes doses de fósforo. Revista Brasileira de Fruticultura, 34(2), 442-450. https://doi.org/10.1590/ S0100-29452012000200017

Zucareli, C., Ramos Junior, E. U., Oliveira, M. A., Cavariani, C., \& Nakagawa, J. (2010). Índices biométricos e fisiológicos em feijoeiro sob diferentes doses de adubação fosfatada. Semina: Ciências Agrárias, 31(1), $1313-1324$.

\section{Copyrights}

Copyright for this article is retained by the author(s), with first publication rights granted to the journal.

This is an open-access article distributed under the terms and conditions of the Creative Commons Attribution license (http://creativecommons.org/licenses/by/4.0/). 